\section{Pigmented Villonodular Synovitis of the Spine: Report of a Lumbar Case}

\section{Spinal Pigmente Villonodular Sinovitis: Lomber Olgu Sunumu}

\begin{abstract}
Pigmented villonodular synovitis is a benign proliferative disease of the synovial structures. This disease is most commonly seen in the extremities, and spinal involvement is extremely rare. In the relevant literature, 53 cases have been reported. We present a 66-year-old female patient with a long history of back pain, which progressed and radiated to the left leg over a period of 2 months. The patient also had a mass in the lumbar region on the grounds of spinal degenerative changes. Following gross total excision, the diagnosis was established by histopathology. In this report, we present our experience and discuss our neuroradiological and clinical findings.
\end{abstract}

KEYWORDS: Pigmented villonodular synovitis, Spine, Vertebral spine tumor

\section{ÖZ}

Pigmente villonoduler sinovitis, sinoviyal yapıların benign proliferatif bir hastalığıdır. Genellikle ekstremitelerde görülürler ve spinal tutulum oldukça nadirdir. Literatürde şimdiye dek 53 olgu bildirilmiştir. Bu olguda uzun zamandır bel ağrısı şikayeti olan ve son 2 aydır ağrısı sol bacağına yayılan, 66 yaşındaki bayan hasta, spinal dejeneratif hastalık zemininde, lomber bölgeye lokalize bir kitle ile başvurmuştur. Gross total rezeksiyonu takiben tanı histopatolojik olarak konulmuştur. Yazımızda hastalığın nöroradyolojik ve klinik bulgularını tartışarak geçmiş tecrübelerimizi sunmaktayız.

ANAHTAR SÖZCÜKLER: Pigmente villonoduler sinovitis, Spinal, Vertebral spinal tümörler

\section{Ulas YENER ${ }^{1}$ \\ Deniz KONYA ${ }^{2}$ \\ Suheyla BOZKURT ${ }^{3}$ \\ Serdar OZGEN ${ }^{4}$}

1,2,4 Marmara University, Faculty of Medicine, Department of Neurosurgery, Altunizade, İstanbul, Turkey

3 Marmara University, Faculty of Medicine, Department of Pathology, Altunizade, İstanbul, Turkey

Received : 06.12.2008

Accepted : 16.07.2009

Correspondence address:

Deniz KONYA

Acibadem Cad. Ibrahimaga Kon.

A6 Blok D:23

34660 Kadikoy/lstanbul, Turkey

Phone : +90 5337351293

Fax : : +90216327 5249

E-mail : drdkonya@hotmail.com 


\section{INTRODUCTION}

Pigmented villonodular synovitis (PVNS) is a well-characterized slowly progressive mass lesion of synovial membrane with uncertain etiology $(2,7,21)$. It was first described by Jeff et al. in 1941 as a villose or nodular proliferation of the synovial tissues with pigmentation because of the presence of the hemosiderin (10). PVNS occurs predominantly in the knee and hip joints $(3,6)$. In the spine, PVNS usually originates from the vertebral articular facet joints and presents most commonly as pain. Involvement of the axial skeleton is extremely rare and only 53 cases have been reported in the literature. Therefore, information regarding the natural history, treatment, and prognosis of PVNS is growing, but it remains limited. Although the lesion is usually asymptomatic, it may cause pain, tenderness, mild to moderate neurological dysfunction leading to acute paraparesis. Thus, in this report, a case of PVNS of lumbar (L) 2 with a low back pain has been presented, and a summary of 53 cases previously reported in the literature has been provided.

\section{CASE REPORT}

A 66-year-old female patient was admitted with a long history of back pain, which progressed and radiated to the left leg over a period of 2 months. The patient had also claudication component. Her walking distance reduced to 100 meters per day. Straight leg raising test was limited to $40^{\circ}$ on the left. Her medical history included unsuccessful physical therapy. There were no sphincter disturbances, no history of trauma, and no family history of metabolic or neurologic diseases. The sensory examination revealed hypoesthesia in the lower limbs. Pinprick test and temperature sensation were normal. The patient's gait was normal. Plain radiographs of the lumbar spine revealed osteophytic degenerations. Magnetic resonance imaging (MRI) of the lumbosacral spine showed that a heterogeneous tissue surrounding the L2 facet joint replaced the fat tissue of the lumbar vertebra. The mass protruded into the spinal canal but did not invade the vertebral bone and displaced the spinal cord to the anterior (Figure 1). Axial MRI and computed tomography (CT) scan demonstrated the presence of a spinal stenosis at the level of the L2 lamina because of the mass lesion and it was most severe at L4 due to degenerative changes (Figure 2). The results of

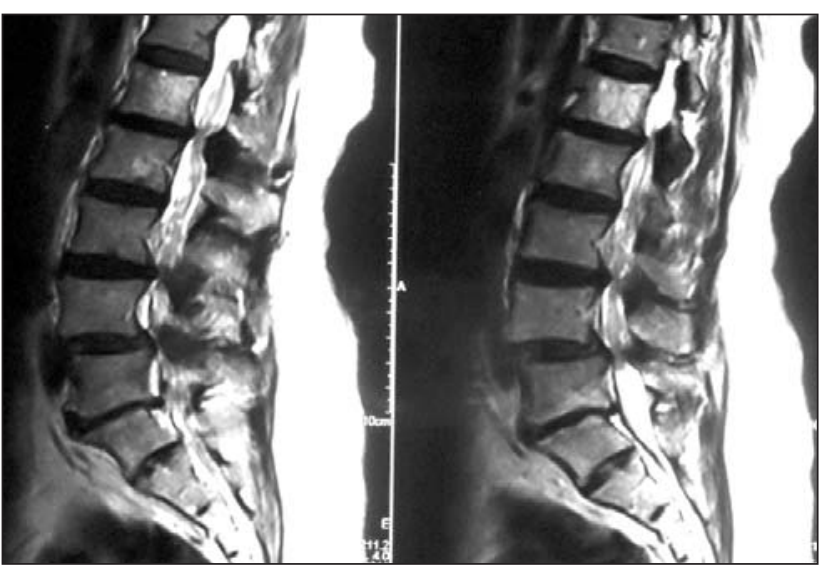

Figure 1: T2-weighted sagittal lumbar MRI shows a low intensity expansile mass arising from the spinous process and right lamina of L2 vertebrae which also causes spinal stenosis.

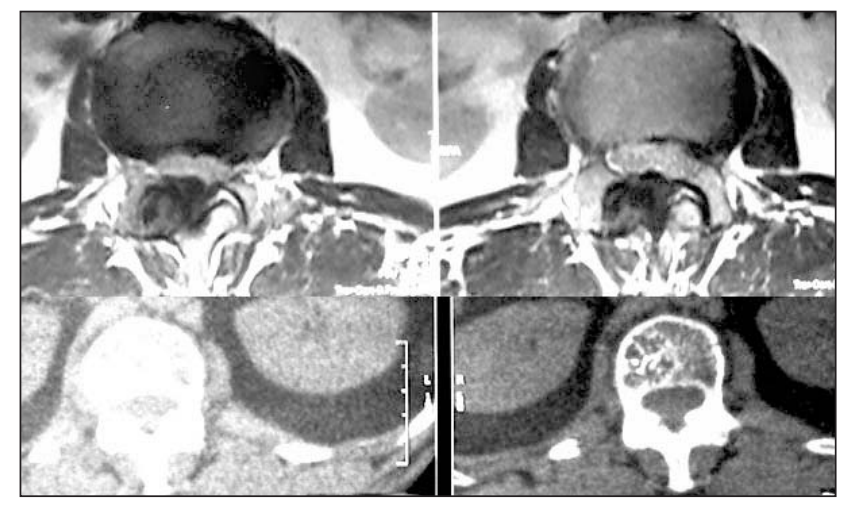

Figure 2: (Upper) : T2 weighed axial MRI showing epidural mass with the displacement of thecal sac anteriorly. (Lower): CT scan at level L2 showing no bone erosion.

hematologic and biochemical investigations were within normal range.

The patient was taken to the operating room for decompressive surgery and resection of the mass. The patient was positioned in prone position, and a midline lumbar incision was made from L1 to L5 lamina to expose the involved segments. First, lumbar decompressive L4 laminectomy was performed for the spinal stenosis, and then L2 laminectomy was performed for the tumoral mass which was located just under the ligamentum flavum (Figure 3). After the ligamentum flavum of the L2 vertebra was opened, pathological fibrous, dark brown-red, avascular tissue was found. The mass was dissected from the dural sac carefully and removed en bloc with a clean plane of dissection along the dura. After the laminectomies, we 
determined spinal intability in the related segments intraoperatively, so the fusion was carried out using allograft material (Tutogen Medical $\mathrm{GmbH}$, Neunkirchen am Brand, Germany) and L2-L3-L4-L5 transpediculer screws (Tasarım Medikal, Istanbul, Turkey). Histopathological examination of the specimen showed a hypercellular lesion composed of mononuclear cells, multinucleated giant cells mostly arranged in nodules. There were also large foam cells, macrophages loaded with hemosiderin and rare mitosis (Figure 4). Postoperative MRI showed no residual disease. After two months of surgery, the patient's symptoms resolved immediately and her neurological examination was normal.

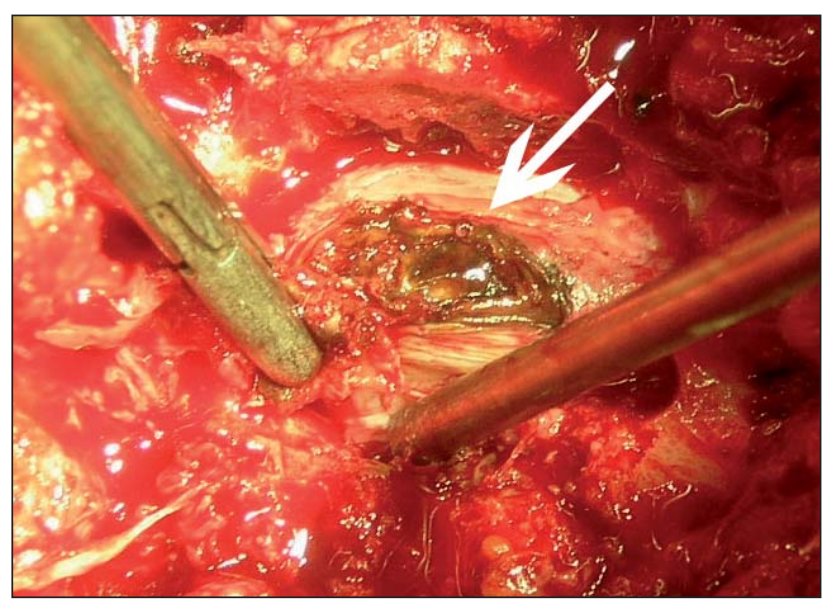

Figure 3: Peroperative photography shows the brownish yellow color mass, which lies over the dura.( Black arrow).

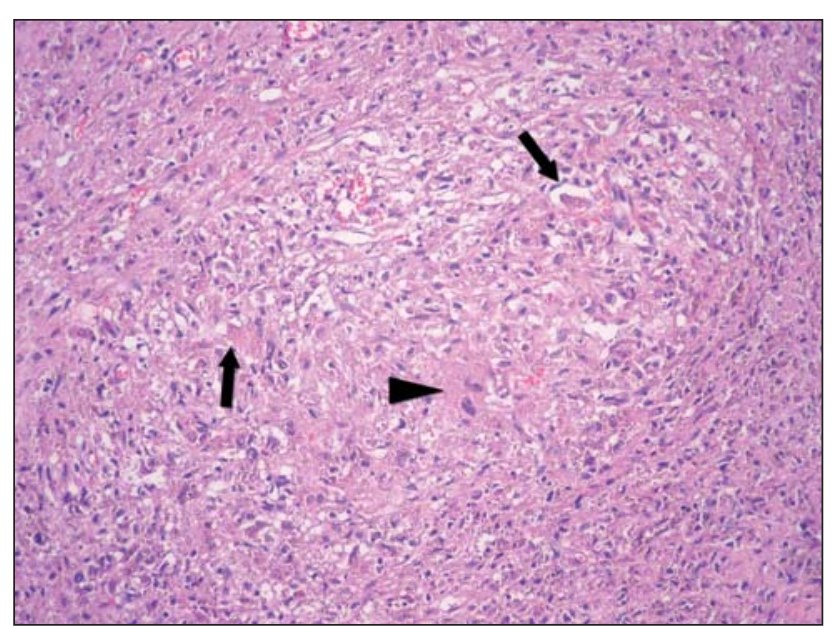

Figure 4: Figure 4:Polymorphic infiltrate compose of small histiocytes (arrow head), and hemosiderin containing histiocytes (arrows) in dense fibrous tissue (HEE, X 100).

\section{DISCUSSION}

The lesion has been termed as fibrous histiocytoma of the synovium, nodular synovitis, fibrous histiocytoma of synovium, and giant cell synovioma (5). However, in 1941 Jeff et al proposed the term "pigmented villonodular synovitis" (10). Since then, it has been used as a general term in the literature. In 1980, Kleinman reported the first case of spinal PVNS (12). To date, there have been a total of only 53 cases reported in the literature.

The estimated incidence is 1.8 case per million (16). The median age at presentation is 40 years with a range of 13 to 84 years. There is slight female dominance with 30 female to 23 male cases. Of the 53 cases, the masses of $23(44 \%)$ were located in the cervical spine; 8 (15\%) in the thoracic spine; and 22 $(41 \%)$ in the lumbosacral spine. The cervical vertebrae have a higher incidence of involvement compared with the lumbar and thoracic vertebrae (Table I).

The etiology of the lesion remains a question. The commonly proposed etiologies are neoplasm, inflammation, trauma, and metabolic derangement (11). The high cellularity, tendency for recurrence, and some cases of malignant behavior support a neoplastic process (5). In addition, the presence of plasma cells, histiocytes, and infiltrating macrophages are associated with inflammatory processes. Hemorrhage after trauma is mentioned but there are no statistically confirmed data that show the relation between trauma and the lesion $(1,15,17)$. Hemophilic and Charcot joints fail to develop. Villonodular synovitis has been reported in the literature (6). In one case, trisomy 7 was documented suggesting that some cases of PVNS represent clonal, neoplastic proliferations (20).

Morphologically, it is described in two forms. Localized form affects only a part of the joint and involves the small joint of the hand/feet. Diffuse form, the more common form that affects the entire synovium occurring in $75 \%$ of all cases, involves larger joints such as the knee and hip joints. Microscopically, matrix is collagenous and composed of proliferative synovial cells, foamy macrophages containing lipid and hemosiderin, sheets of histiocytes, plasma cells, giant multinucleated cells, and xanthoma cells. Abnormal mitosis and atypical nuclei are rare. The amount of hemosiderin pigment in the lesion is related to the 
Table I

\begin{tabular}{|c|c|c|c|c|c|c|}
\hline Author/year & Location & Age/ sex & Epidural mass & Clinic & Type of Resection & Follow up \\
\hline Kleinman et al. (1980) & C3-6 & $65 \mathrm{~F}$ & Yes & Subacute myelopathy & Biopsy & No recurrence (8 months)) \\
\hline Campbell \&Wells (1982) & L4-5 & $54 \mathrm{~F}$ & Yes & None & GTR & No recurrence (31 months) \\
\hline \multirow[t]{2}{*}{ Savitz et al. (1982) } & L4-5 & $53 \mathrm{~F}$ & Yes & Radiculopathy & $\mathrm{NA}$ & NA \\
\hline & L4-5 & $71 \mathrm{~F}$ & Yes & Radiculopathy & $\mathrm{NA}$ & NA \\
\hline \multirow[t]{2}{*}{ Pulitzer \& Reed (1984) } & C1-4 & $35 \mathrm{~F}$ & No & None & GTR & No recurrence (11 yrs) \\
\hline & L5-S1 & $23 \mathrm{M}$ & Yes & None & GTR & NA \\
\hline Valat et al. (1984) & L4-L5 & $57 \mathrm{M}$ & No & $\mathrm{NA}$ & GTR & NA \\
\hline \multirow{2}{*}{ Weidner et al. (1986) } & L5-6 & $48 \mathrm{~F}$ & Yes & Radiculopathy & GTR & Two Recurrences 4-8 months \\
\hline & L4-5 & $34 \mathrm{~F}$ & Yes & None & STR & No recurrence $(8 \mathrm{yrs})$ \\
\hline Retrum et al. (1987) & L5-S1 & $81 \mathrm{~F}$ & Yes & None & GTR & NA \\
\hline Karnesis et al. (1990) & $\mathrm{C} 7$ & $37 \mathrm{~F}$ & No & None & GTR & No recurrence (79 months) \\
\hline \multirow[t]{2}{*}{ Khoury et al. (1990) } & L4-5 & $61 \mathrm{~F}$ & Yes & None & GTR & NA \\
\hline & $\mathrm{C} 4-\mathrm{C} 5$ & $84 \mathrm{M}$ & Yes & Cervical myelopathy & GTR & NA \\
\hline Mahmood et al. (1992) & $\mathrm{C} 5-\mathrm{C} 7$ & $42 \mathrm{~F}$ & Yes & None & GTR & NA \\
\hline Kuwabara et al. (1992) & T8-11 & $25 \mathrm{~F}$ & Yes & $\mathrm{NA}$ & $\mathrm{STR}+\mathrm{RT} /$ Chemo & No recurrence $(7 \mathrm{yrs})$ \\
\hline Titelbaum et al. (1992) & L4-L5 & $51 \mathrm{~F}$ & NA & NA & GTR & NA \\
\hline Clark et al. (1993) & L4-L5 & $23 \mathrm{M}$ & Yes & Acute paraparesis & GTR & No recurrence (42 months) \\
\hline Zirh et al (1995) & L4-L5 & $48 \mathrm{~F}$ & Yes & Radiculopathy & GTR & No recurrence (6 months) \\
\hline Gezen et al. (1996) & T10-11 & $19 \mathrm{M}$ & Yes & Acute paraparesis & GTR & No recurrence (16 months) \\
\hline \multirow[t]{12}{*}{ Gianini et al. (1996) } & $\mathrm{C} 5$ & $37 \mathrm{~F}$ & No & $\mathrm{NA}$ & GTR & Recurrence (10 months) - Nr. (9 yrs) \\
\hline & L5-S1 & $29 \mathrm{~F}$ & No & $\mathrm{NA}$ & GTR & Recurrence (12 months) - Nr (23 months) \\
\hline & C7 & $37 \mathrm{~F}$ & Yes & NA & GTR & No recurrence (66 months) \\
\hline & $\mathrm{C} 4-\mathrm{C} 5$ & $38 \mathrm{M}$ & Yes & NA & GTR & Recurrence (12 months) - Nr (55 months) \\
\hline & T11 & $40 \mathrm{M}$ & NA & NA & GTR & No recurrence (64 months) \\
\hline & T3 & $21 \mathrm{~F}$ & No & $\mathrm{NA}$ & GTR & No recurrence (53 months) \\
\hline & $\mathrm{T} 7-8$ & $23 \mathrm{M}$ & Yes & $\mathrm{NA}$ & GTR & No recurrence (42 months) \\
\hline & $\mathrm{C} 5$ & $43 \mathrm{M}$ & Yes & $\mathrm{NA}$ & GTR & No recurrence (36 months) \\
\hline & L3 & $42 \mathrm{M}$ & NA & NA & STR & No recurrence (14 months) \\
\hline & L3 & $67 \mathrm{M}$ & Yes & NA & NA & NA \\
\hline & $\mathrm{C} 6$ & $26 \mathrm{M}$ & Yes & $\mathrm{NA}$ & GTR & No recurrence (11 months) \\
\hline & $\mathrm{C} 5-6$ & $44 \mathrm{M}$ & Yes & $\mathrm{NA}$ & Biopsy / GTR & No recurrence (6 months) \\
\hline Bruecks et al. (2001) & T8 & $13 \mathrm{~F}$ & Yes & Myelopathy & GTR & NA \\
\hline Dimeco et al. (2001) & L3-L4 & $70 \mathrm{~F}$ & Yes & Radiculopathy & GTR & No recurrence (1 year) \\
\hline Sampathkumar et al. (2001 & L5-S1 & $71 \mathrm{~F}$ & Yes & Radiculopathy & GTR & No recurrence (3 years) \\
\hline \multirow[t]{15}{*}{ Furlong \& Motemedi (2003) } & Sacrum & $17 \mathrm{M}$ & Yes & $\mathrm{NA}$ & GTR & NA \\
\hline & T4-5 & $21 \mathrm{~F}$ & Yes & $\mathrm{NA}$ & GTR & NA \\
\hline & $\mathrm{C} 2-3$ & $23 \mathrm{M}$ & Yes & NA & STR/GTR/RT & Recurrence (4 years) - Nr (5 years) \\
\hline & C3-5 & $25 \mathrm{M}$ & Yes & $\mathrm{NA}$ & GTR & NA \\
\hline & L4-L5 & $25 \mathrm{~F}$ & Yes & $\mathrm{NA}$ & STR/GTR & Recurrence (2 years) \\
\hline & L4 & $29 \mathrm{~F}$ & No & NA & EN BLOC RESEC. & No recurrence (4 years) \\
\hline & $\mathrm{C} 5-6$ & $31 \mathrm{M}$ & No & $\mathrm{NA}$ & GTR & No recurrence ( 9 years) \\
\hline & C3-4 & $32 \mathrm{~F}$ & Yes & $\mathrm{NA}$ & GTR & No recurrence ( 3 years) \\
\hline & C3-4 & $32 \mathrm{M}$ & NA & NA & STR/STR/RT & No recurrence (2 years) \\
\hline & $\mathrm{C}$ ? & $35 \mathrm{M}$ & NA & NA & GTR/RT & No recurrence ( 7 years) \\
\hline & $\mathrm{C} ?$ & $39 \mathrm{~F}$ & NA & $\mathrm{NA}$ & BIOPSİGTR & Recurrence (2 years)- Nr. (10 years) \\
\hline & $\mathrm{C} 5-6$ & $39 \mathrm{~F}$ & Yes & $\mathrm{NA}$ & GTR & NA \\
\hline & $\mathrm{C} 5-6$ & $43 \mathrm{~F}$ & Yes & NA & STR & NA \\
\hline & $\mathrm{C} ?$ & $44 \mathrm{M}$ & NA & $\mathrm{NA}$ & GTR/RT & No recurrence (4 months) \\
\hline & C4-5 & $44 \mathrm{~F}$ & Yes & $\mathrm{NA}$ & Biopsy & NA \\
\hline Parmar et al. (2004) & $\mathrm{C} 5-\mathrm{C} 6$ & $43 \mathrm{M}$ & Yes & $\mathrm{NA}$ & GTR & No recurrence (6 months) \\
\hline Hansen et al. (2007) & $\mathrm{T} 6-\mathrm{T} 7$ & $17 \mathrm{M}$ & Yes & $\mathrm{NA}$ & GTR & NA \\
\hline Hermann et al. (2007) & L3-L5 & $50 \mathrm{M}$ & NA & NA & Biopsy/GTR & No recurrence (2 years) \\
\hline Oda et al. (2007) & L5-S1 & $53 \mathrm{~F}$ & Yes & Radiculopathy & Biopsy/GTR/Chemo & Two recurrences $(10-7$ months $)$ \\
\hline
\end{tabular}

Abbreviations: M, male; F, female; C, cervical; T, thoracal; L, lumbar; GTR, gross total removal; STR, subtotal removal; RT, radiation therapy; Chemo, chemotherapy; $\mathbf{N r}$, no recurrence; NA, not available 
extent of mechanical tension that the lesion undergoes (18).

The main presenting complaint is usually intermittent pain related to the monoarticular arthritis. Radiculopathy and myelopathy are present in half of the cases because of the mass effect of the lesion. Our patient similarly presented with bilateral pain due to lumbar stenosis at the lumbar 4 vertebra. Gradually, the volume of the mass lesion had increased, resulting in radiculopathy and radiating pain to the left limb.

Radiographic features of PVNS have been reported in detail primarily in the extremities $(4,7,9)$. Plain films can show erosive bone changes and occasionally a definable soft tissue mass (4). In our case, plain roentgenograms were unremarkable. Computed tomography shows hyperdense enhancing soft tissue mass which can be easily confused as a disc herniation and bone erosions (22). Calcification is rarely seen. Magnetic resonance imaging is the best choice of the diagnostic test. On MRI, the mass usually has mixed signal intensity on T2-weighted images due to the presence of hemosiderin and hemorrhage (19). The lesion often shows marked enhancement after contrast injection.

Differential diagnosis includes heamangioblastoma, heamangiopericytoma, tendinous xanthoma, large cell lymphoma, epitheloid Schwannoma or carcinoma, primary bone tumors, hypertrophic synovitis following a disc herniation $(14,23)$.

Surgical resection is the primary treatment for spinal PVNS as was in our case. Gross total resection must be the aim of the treatment. The recurrence rate of appendicular PVNS has been reported to be $17 \%$ $48 \%$ in different series $(3,8,16)$. In the postoperative period, the risk of recurrence should be kept in mind, and thus, routine imaging should be performed, especially MRI if possible. In cases of the recurrence or residual tumor, re-resection can be done. The role of radiation therapy has not been clarified. Local irradiation as initial treatment has been used since 1940s $(9,13)$. Because of the side effects, adjuvant radiotherapy can be used after subtotal resection due to accessibility of the lesion or after local recurrence.

In summary, PVNS is a rare entity of the axial skeleton that most commonly affects the lumbar region and is in close association with the facet joints.
In our patient, it was located in the lumbar region, which is formed on the basis of degenerative spinal processes. Therefore, awareness of this lesion is important because it may mimic the lesions of many other neoplastic and non-neoplastic conditions of this region..

\section{REFERENCES}

1. Bentley G, McAuliffe T: Pigmented villonodular synovitis. Ann Rheum Dis 49:210-211, 1990

2. Byers PD, Cotton RE, Deacon OW, Lowy M, Newman PH, Sisson HA, Thomson AD: The diagnosis and treatment of pigmented villonodular synovitis. J Bone Joint Surg Br 50:290305, 1968

3. Docken WP: Pigmented villonodular synovitis: a review with illustrative case reports. Semin Arthritis Rheum 9:1-22, 1979

4. Dorwart RH, Genant HK, Johnston WH, Morris JM: Pigmented villonodular synovitis of synovial joints: Clinical, pathologic, and radiologic features. AJR Am J Roentgenol 143:877-885, 1984

5. Gezen F, Akay KM, Aksu AY, Beduk A, Seber N: Spinal pigmented villonodular synovitis: A case report. Spine 21:642645, 1996

6. Giannini C, Scheithauer BW, Wenger DE, Unni KK: Pigmented villonodular synovitis of the spine: A clinical, radiological, and morphological study of 12 cases. J Neurosurg 84:592-597, 1996

7. Goldman AB, DiCarlo EF: Pigmented villonodular synovitis. Diagnosis and differential diagnosis. Radiol Clin North Am 26:1327-1347, 1988

8. Granowitz SP, D'Antonio J, Mankin HL: The pathogenesis and long-term end results of pigmented villonodular synovitis. Clin Orthop Relat Res:335-351, 1976

9. Greenfield MM, Wallace KM: Pigmented villonodular synovitis. Radiology 54:350-356, 1950

10. Jaffe HL LL, Sutho CJ: Pigmented villonodular synovitis, bursitis and tenosynovitis: A discussion of the synovial and bursal equivalents of the tenosynovial lesions commonly denoted as xanthoma, xanthogranuloma, Giant Cell tumour, or myeloplaxoma of the tendon sheat, with some consideration of the tendon sheat lesion itself. Acch Pathol 31:731-765, 1941

11. Karnezis TA, McMillan RD, Ciric I: Pigmented villonodular synovitis in a vertebra. A case report. J Bone Joint Surg Am 72:927-930, 1990

12. Kleinman GM, Dagi TF, Poletti CE: Villonodular synovitis in the spinal canal: case report. J Neurosurg 52:846-848, 1980.

13. Klompmaker J, Veth RP, Robinson PH, Molenaar WM, Nielsen HK: Pigmented villonodular synovitis. Arch Orthop Trauma Surg 109:205-210, 1990

14. Mahmood A, Caccamo DV, Morgan JK: Tenosynovial giantcell tumor of the cervical spine. Case report. J Neurosurg 77:952-955, 1992

15. Morris CJ, Blake DR, Wainwright AC, et al: Relationship between iron deposits and tissue damage in the synovium: An ultrastructural study. Ann Rheum Dis 45:21-26, 1986

16. Myers BW, Masi AT: Pigmented villonodular synovitis and tenosynovitis: a clinical epidemiologic study of 166 cases and literature review. Medicine (Baltimore) 59:223-238, 1980 
17. Nielsen AL, Kiaer T: Malignant giant cell tumor of synovium and locally destructive pigmented villonodular synovitis: Ultrastructural and immunohistochemical study and review of the literature. Hum Pathol 20:765-771, 1989

18. Parmar HA, Sitoh YY, Tan KK, Teo J, Ibet SM, Hui F: MR imaging features of pigmented villonodular synovitis of the cervical spine. AJNR Am J Neuroradiol 25:146-149, 2004

19. Poletti SC, Gates HS 3rd, Martinez SM, Richarson WJ: The use of magnetic resonance imaging in the diagnosis of pigmented villonodular synovitis. Orthopedics 13:185-190, 1990

20. Ray RA, Morton CC, Lipinski KK, Corson JM, Fletcher JA: Cytogenetic evidence of clonality in a case of pigmented villonodular synovitis. Cancer 67:121-125, 1991

21. Schwartz HS, Unni KK, Pritchard DJ: Pigmented villonodular synovitis. A retrospective review of affected large joints. Clin Orthop Relat Res:243-255, 1989

22. Titelbaum DS, Rhodes CH, Brooks JS, Goldberg HI: Pigmented villonodular synovitis of a lumbar facet joint. AJNR Am J Neuroradiol 13:164-166, 1992

23. Zırh TA, Pamir MN, Öktenoğlu T, Sav A, Erzen C: Pigmented Villonodular Synovitis Mimicking Lumbar Disc Herniation. Neuro-Orthopedics 85:78-81, 1995 